АНАЛІЗ ВИМОГ ДО МЕДІАТОРА

\title{
ANALYSIS OF REQUIREMENTS FOR MEDIATOR
}

\author{
Петренко Н.О., к.ю.н., \\ доцент кафедри професійних та спеціальних дисциплін \\ Херсонський факультет Одеського державного університету внутрішніх справ
}

У статті представлено дослідження інституту медіації в Україні. Так, Указом Президента України затверджено Стратегію розвитку системи правосуддя та конституційного судочинства на 2021-2023 роки. Зокрема, одним із шляхів розвитку судової системи є розвиток альтернативного (позасудового) та досудового врегулювання спорів, серед яких і медіація. А вже 16 листопада 2021 р. ухвалено у другому читанні Закон України «Про медіацію», що стає новим етапом розвитку та становлення медіації в державі. Досліджуваний спосіб вирішення спорів існує в Україні вже майже 25 років, однак визнання та підтримка з боку держави не забезпечували належної довіри суспільства до даного способу врегулювання конфрліктів. Так, недовіра до судової влади та криза судової системи призводять до необхідності впровадження способу вирішення спорів альтернативного суду. Закон Україні «Про медіацію» $€$ «рамковим», тобто визначає загальні вимоги до процедури медіації та медіатора, а вирішення більшості питань залишається за медіаторською спільнотою. Так, у статті визначаються три групи вимог до статусу медіатора. По-перше, кваліфікаційні - вік, освіта, стаж роботи тощо. По-друге, етичні вимоги - нейтральність, незалежність, неупередженість, компетентність та конфіденційність. Третя група - вимоги до особистості медіатора, а саме вербальні і невербальні навички комунікації, уміння налагоджувати зв'язок, розуміння людей та емоційний інтелект. Кваліфікаційні й етичні вимоги можуть закріплюватися як на законодавчому рівні, так і шляхом ухвалення відповідних актів об'єднаннями медіаторів. Вимоги до особи медіатора не можуть бути закріплені у відповідних актах, проте мають велике значення для професії медіатора. Відсутність чітко визначених законодавством вимог до медіатора свідчить про високу довіру до професії. Так, медіатори - це фахівці, які допомагають людям домовлятися, тож фрактично почати вони мають із себе.

Ключові слова: медіатор, правовий статус медіатора, вимоги до медіатора, кваліфікаційні вимоги до медіатора, етичні вимоги до медіатора.

The article presents a study of the Institute of Mediation in Ukraine. Thus, the Decree of the President of Ukraine approved the Strategy for the Development of the Justice System and Constitutional Judiciary for 2021-2023. In particular, one of the ways to develop the judicial system is the development of alternative (out-of-court) and pre-trial settlement of disputes, including mediation. And on November 16, 2021, the second reading of the Law of Ukraine "On Mediation" was adopted, which becomes a new stage in the development and formation of mediation in the state. At the same time, the researched way of resolving disputes has existed in Ukraine for about 25 years, but the recognition and support of the state did not provide adequate public confidence in this way of resolving conflicts. Thus, distrust of the judiciary and the crisis of the judiciary lead to the need to introduce a method of resolving disputes in alternative courts. The Law of Ukraine "On Mediation" is "framework", i.e. it defines the general requirements for the mediation procedure and the mediator, and the solution of most issues is left to the mediation community. Thus, the article defines three groups of requirements for the status of a mediator. The first ones are qualifications - age, education, work experience, etc. The second is ethical requirements - neutrality, independence, impartiality, competence and confidentiality. The third group of requirements is the requirements for the mediator's personality - verbal and non-verbal communication skills, communication skills, understanding of people and emotional intelligence. At the same time, qualification and ethical requirements can be established both at the legislative level and by the adoption of relevant acts by associations of mediators. In turn, the requirements for the mediator's identity cannot be enshrined in the relevant acts, but are important for the mediator's profession. The lack of clearly defined legal requirements for a mediator indicates a high level of trust in the profession. Yes, mediators are people who help people negotiate, so they actually have to start with themselves.

Key words: mediator, legal status of mediator, requirements to mediator, qualification requirements to mediator, ethical requirements to mediator.

Початком упровадження медіації у світі вважається друга Паундська конференція (the second Pound Conference), яка відбулася 7-9 квітня 1976 р. у США. На конференції з доповіддю виступив професор Гарвардської школи права Френк Сандер. Він виклав своє бачення суду майбутнього, у якому спори розподіляються за різним критеріям - деякі 3 них необхідно розглядати в судовому порядку, а інші мають передаватися для застосування інших процедур, як-от фасилітація, медіація або арбітраж [1].

Що стосується України, то медіації в нашій державі налічується вже 25 років. Попри такий тривалій строк застосування медіації, вона все ще перебуває на шляху розвитку та становлення. Наведене зумовлюється тим, що в поширенніі даного інституту зацікавлені лише незначна чисельність правників та психологів.

Хоча впродовж останніх років спостерігається нагальна потреба суспільства в упровадженні альтернативних способів вирішення спорів. Поглиблення кризи судової системи, втрата довіри до суду 3 боку людей зумовлюють необхідність розвитку нових способів вирішення спорів, окрім суду. Одним із таких способів має стати медіація. Деякі крокі щодо запровадження медіації в Україні вже зроблені, зокрема й на законодавчому рівний. Так, наказом Міністерства соціальної політики України від 17 серпня 2016 р. № 892 затверджено Державний стандарт соціальної послуги посередництва (медіації), яким визначено зміст, обсяги, умови та порядок надання соціальної послуги посередництва (медіації) особам / сім'ям, які перебувають у складних життєвих обставинах [2]. Нещодавно Указом Президента України затверджено Стратегію розвитку системи правосуддя та конституційного судочинства на 2021-2023 pр. Зокрема, одним із шляхів розвитку судової системи є розвиток альтернативного (позасудового) та досудового врегулювання спорів, серед яких і медіація [3]. Наступним кроком стало ухвалення 16 листопада 2021 р. у другому читанні Закону України «Про медіацію», що $є$ новим етапом у формуванні та становленні досліджуваного інституту. Окрім того, положення про медіацію імплементовано у процесуальне законодавство держави, а саме Цивільний процесуальний кодекс України, Господарський процесуальний кодекс України, Кодекс адміністративного судочинства України.

Отже, актуальність і необхідність запровадження медіації як способу вирішення спору, який є альтернативним суду, визнається не тільки юридичною спільнотою, а й державою.

У ст. 3 Директиви СС 2008/52/ СС «Про деякі аспекти медіації у цивільних і комерційних справах» від 21 травня 2008 р. закріплено, що медіація (mediation) - структурований процес, незалежно від його назви або посилання 
на нього, за допомогою якого дві або більше сторін спору намагаються самостійно, на добровільній основі досягти згоди для вирішення спору за підтримки медіатора [5].

Тобто одним з учасників та ключовою фігурою процесу медіації $\epsilon$ медіатор. Саме медіатор забезпечує проведення процедури та допомагає сторонам налагодити комунікацію.

До ухвалення Закону Україні «Про медіацію» правовій статус медіатора був практично не врегульований. Спільнота медіаторів та прихильників даної процедури збільшується щодня. Саме тому питання правового статусу медіатора, кваліфікаційні й етичні вимог до медіатора є нагальними питаннями, які потребують не тільки вивчення, а і відповідного, якісного унормування.

Так, «Класифікатор професій ДК 003:2010», затверджений наказом Держспоживстандарту України від 28 липня 2010 р. № 327, містить таку професію, як фахівець 3 урегулювання конфліктів та медіації в соціально-політичний сфері [4], однак професії медіатор немає. Тобто до ухвалення спеціального закону про медіацію в Україні не було і відповідних кваліфікаційних вимог.

Окрім кваліфікаційних вимог, до медіатора висуваються й етичні вимоги. Специфікою розвитку медіації в Україні є саме те, що такі етичні вимоги були сформульовані раніше за кваліфікаційні критерії. Так, кодекси етики медіаторів були розроблені та затверджені громадськими організаціями медіаторів, які існують у країні. Зокрема громадською організацією «Національна асоціація медіаторів України» 7 грудня 2017 р. розроблено та затверджено Кодекс етики медіатора НАМУ; Громадською організацією «Український центр медіації» також розроблено власний кодекс етики.

Етичні кодекси мають на меті закріплення засад та правил поведінки відповідних професій, що свідчить про формування відповідної професії в суспільстві. Отже, нині вже можна говорити про затвердження відповідного правового статусу медіатора та необхідність подальшого автономного формування такої професії, як медіатор.

Окрім кваліфікаційних і етичних вимог, важлива особистість медіатора, яка проявляється, серед іншого, у здатності дотримуватися засад професійної етики. Особистість медіатора є невід'ємною частиною процесу. Зокрема, О. Цільмак у дослідженні професійно важливих якостей медіатора визначає такі: психологічні якості (активність, витривалість, уважність тощо); інтелектуальність (виваженість, гнучкість, винахідливість тощо); моральні (ввічливість, вірність, безкорисність); комунікативні (доступність, контактність тощо); специфічні (інтуїція, емпатійність) та інші [6, с. 65].

Узагальнюючи, можна визначити, що вимоги, які висуваються до особи медіатора, можна поділити на три групи. Перші - кваліфікаційні, які встановлюються відповідними законодавчими актами. До таких вимог належать вік, освіта, стаж роботи, досвід у певній сфері тощо.

Другі - етичні вимоги. Дане питання може бути врегульовано як на рівні медіаторської спільноти шляхом розроблення та затвердження відповідних етичних кодексів, так і законодавством.

Третя група вимог - вимоги до особистості медіатора. Такі вимоги не можуть бути унормовані в жодному акті, проте їх формування та розвиток $є$ вкрай важливими для медіатора.

Так, кожна із зазначених груп вимог потребує окремого дослідження.

Кожна країна, яка легалізує медіацію як спосіб вирішення конфліктів, у законодавстві закріплює відповідні кваліфікаційні вимоги щодо медіатора. Нещодавно ухвалений Закон України «Про медіацію» визначає, що медіатором може бути фізична особа, яка пройшла базову підготовку медіатора в Україні або за кордоном (ч. 1 ст. 9). Базова підготовка медіаторів здійснюється за програмою обсягом (тривалістю) не менше 90 годин навчання, зокрема й не менше 45 годин практичного навчання. У ч. 2 ст. 9 зазначеного вище Закону визначено, що медіатором не може бути особа, яка має судимість, особа, цивільна дієздатність якої обмежена, або недієздатна особа. Отже, національним законодавством установлені мінімальні кваліфікаційні вимоги до статусу медіатора. Проте в ч. 4 ст. 9 Закону України «Про медіацію» закріплено, що об'єднання медіаторів та суб'єкти, що забезпечують проведення медіації, можуть встановлювати додаткові вимоги до медіаторів, яких вони включають до своїх реєстрів, зокрема щодо наявності спеціальної підготовки, віку, освіти, практичного досвіду тощо. Тобто професія медіатора в Україні має стати саморегульованою, медіаторська спільнота має право шляхом досягнення відповідних домовленостей самостійно визначити, у разі необхідності, вимоги до медіатора.

Для порівняння, у Законі Республіки Казахстан від 28 січня 2011 р. № 401-IV «Про медіацію» закріплено, що діяльність медіатора на професійній основі може здійснювати особа, яка має вищу освіту, досягла 25-річного віку, має документ, який підтверджує проходження навчання за програмою підготовки медіаторів, яка затверджена Урядом Республіки Казахстан, та зазначена в реєстрі професійних медіаторів [7].

У Німеччині також діє окремий законодавчий акт, який регулює інститут медіації, - Закон «Про медіацію» (Mediationsgesetz) від 21 липня 2012 р. Зазначений законодавчий акт не містить вимог до освіти, віку, підготовки медіатора. Відповідно до $\S 5$ зазначеного вище Закону медіатор несе відповідальність за те, щоб шляхом відповідного навчання та регулярного підвищення кваліфікації він володів теоретичними знаннями та практичним досвідом, щоб мати можливість експертно керувати сторонами через медіацію [8].

Так, уважаємо, що на законодавчому рівні мають висуватися мінімальні вимоги до медіатора, які можуть стосуватися його підготовки та підвищення кваліфікації. Саме таким шляхом пішла Україна. Проте відсутність жорстких кваліфікаційних вимог не може бути підставою для невизнання існування медіації як професії та закріплення іiї на законодавчому рівні.

Етичні вимоги до медіатора станом натепер закріплюються відповідними етичними кодексами, які ухвалюються громадськими спільнотами медіаторів. Окрім наведеного, етичні вимоги встановлюються нещодавно ухваленим Законом України «Про медіацію».

I. Мельник визначає професійну етику як систему ціннісних орієнтацій, моральних норм і правил професійної діяльності - професійних підвалин нормативної практики моральності у професії [9, с. 103]. У роботі медіатора саме його професійна етика має пріоритет над кваліфікаційними вимогами щодо віку, досвіду тощо. Зазначене зумовлено тим, що медіатор будує свої роботу із клієнтами на знанні процедури медіації та довірі до нього як до професійного посередника та до процесу.

У 2004 р. ухвалено Європейський кодекс поведінки для медіаторів (European Code Of Conduct For Mediators) [9]

К. Токарєва досліджує етичні засади діяльності медіаторів і навела перелік етичних принципів медіатора, серед яких такі: 1) незалежність, нейтральність та неупередженість; 2) компетентність; 3) тактовності; 4) конфіденційності; 5) повага до професії та культура поведінки $[10$, c. 76$]$. Проте $з$ деякими наведеними засадами погодитися не можна.

Так, під тактовністю авторка розуміє вимоги до медіатора володіти комунікативними навичками, дотримуватися поваги до учасників процедури та всередині професійної групи, бути ввічливим та уникати будь-яких проявів дискримінації $[10$, с. 77]. Проте сама природа процедури медіації та постать медіатора не допускають відсутності комунікативних навичок або грубу поведінку з його боку. 
Так, основним завданням медіатора є не врегулювання конфлікту, а налагодження комунікації між сторонами, що допоможе їм не тільки вирішити спір, а і зберегти стосунки. А особа, у якої не розвинуті комунікативні навички, не зможе допомогти іншим із проблемами комунікації. Тому вважаємо, що виділення толерантності є недоцільним.

Незалежність та нейтральність медіатора означають, що він не $є$ представником жодної зі сторін, тому він незацікавлений в ухваленні конкретного рішення у справі. Водночас нейтральність та незалежність медіатора не означають його відстороненості. Завданням медіатора $\epsilon$ налагодження комунікації між сторонами, що сприяє врегулюванню конфлікту самими учасниками медіації. Неупередженість медіатора означає, що у своїй діяльності він не може давати оцінки сторонам, обставинам конфлікту та рішенням, ухваленим під час процесу.

Щодо компетентності медіатора. Так, дана вимога міститься в Свропейському кодексі поведінки для медіаторів. У ньому визначено, що медіатор повинен бути компетентним і добре розбиратися у процедурі медіації. Це передбачає належне навчання, безперервне оновлення знань і практики медіації з урахуванням відповідних стандартів і правил акредитації [9]. Професійна компетентність медіатора також полягає в тому, що в разі втрати нейтральності, наявності конфлікту інтересів він має повідомити про це сторони, відмовиться від процедури медіації.

Конфіденційність означає, що медіатор не може розголошувати інформацію, яку дізнався під час проведення процедури. Конфіденційним $є$ і сам факт звернення до медіатора. Рівень конфіденційності визначається сумісно сторонами конфлікту, а держава гарантує його дотримання. Останнє реалізується шляхом заборони допитувати медіатора як свідка в цивільному, господарському й адміністративному судочинстві.

Ю. Притика й О. Козляковська вказують на ознаки статусу медіатора, визначають його авторитетність. Так, автори зазначають, що авторитетність особи медіатора та довіра до нього з боку всіх суб'єктів спору є неодмінною передумовою успішного здійснення діяльності медіатора [11]. Але вважаємо, що авторитетність та довіра не є ні тотожними, ні взаємопов' язаними категоріями. Так, формування довіри відбувається саме шляхом дотримання зазначених вище етичних вимог медіатором. А авторитетність може призвести до зайвого емоційного тиску на сторони, у результаті чого мета застосування даної процедури може бути не досягнута.

Що стосується вимог до особистості медіатора, то його діяльність безпосередньо пов'язана 3 роботою 3 людьми та вирішенням ними конфліктів. Така діяльність передбачає володіння не тільки вербальними, а і невербальними навичками комунікації, умінням налагоджувати зв'язок, розуміти людей, емоційним інтелектом. Водночас такі особистісні якості не мають окремого закріплення у відповідник актах, однак їх дослідження має вагоме значення для подальшого розвитку професії медіатора. Особливістю досліджуваних вимог $€$ неможливість їх закріплення та регулювання, проте медіатор може самостійно їх розвивати та напрацьовувати.

Узагальнюючи наведене, можна дійти висновку, що з ухваленням Закону України «Про медіацію» відбувається фактичне визнання державою цього виду альтернативного способу вирішення спорів. Подальший розвиток та підтримка цього процесу мають відбуватися шляхом офіційного визнання професії медіатора. Багаторічний розвиток медіації в Україні, до ухвалення Закону, дозволив сформувати етичні й особистісні вимоги до медіаторів. Мінімальні кваліфікаційні вимоги, закріплені законом, та надання права медіаторській спільноті встановлювати такі вимоги свідчать про автономність професії медіатора і надання можливості медіаторам самостійно визначити вимоги для доступу до професії. Адже медіатори - це люди, які допомагають людям домовлятися, тож фактично почати вони мають із себе.

\section{ЛITEPATYPA}

1. Frank E.A. Sander, Varieties of Dispute Processing, Address Before the National Conference on the Causes of Popular Dissatisfaction with the Administration of Justice, 70 F.R.D. 79, 111. 1976.

2. Державний стандарт соціальної послуги посередництва (медіації) : наказ Міністерства соціальної політики України від 17.08.2016 p. № 892. URL: https://zakon.rada.gov.ua/laws/show/z1243-16\#Text.

3. Про Стратегію розвитку системи правосуддя та конституційного судочинства на 2021-2023 рр. : Указ Президента України від 11.06.2021 p. № 231/2021. URL: https://zakon.rada.gov.ua/laws/show/231/2021\#Text.

4. Класифрікатор профресій ДК 003:2010, затверджений наказом Держспоживстандарту України від 28.07.2010 p. № 327. URL: https:// zakon.rada.gov.ua/rada/show/va327609-10\#n5.

5. Про деякі аспекти медіації у цивільних та господарських правовідносинах : Директива 2008/52/ЄС Європейського парламенту та Ради від 21.05.2008 p. URL: https://zakon.rada.gov.ua/laws/show/994_a95\#Text.

6. Цільмак О. Професійна компетентність медіатора в галузі відновного правосуддя. Правова система: теорія і практика. 2015. № 4. C. 63-65.

7. О медиации : Закон Республики Казахстан от 28.01.2011 г. № 401-IV. URL: https://online.zakon.kz/document/?doc_ id $=30927376 \&$ pos $=3 ;-106 \#$ pos $=3 ;-1067$.

8. Mediationsgesetz (MediationsG) від 21.07.2012 p. URL: https://www.gesetze-im-internet.de/mediationsg/BJNR157710012. html?fbclid=IwAR14w-jcT1ogWAEfws6jc_mPcGq70eiJeQH8Kpfm7y-IFVSYJpnTnvgAk5Y.

9. European Code of Conduct for Mediators. URL: https://www.euromedjustice.eu/en/system/files/20090128130552 adr ec code conduct_en.pdf.

10. Токарєва К. Теоретико-правовий аналіз етичних засад діяльності медіатора. Вісник Академії праці, соціальних відносин і туризмy. 2020. № № 3-4. С. 70-79.

11. Притика Ю., Козляковська О. Медіація, як спосіб вирішення цивільно-правових спорів. URL: http://ilandmanagement. com/ Publication/45. 